\title{
Thai Pre-service Chemistry Teachers' Constructivist Teaching Performances
}

\author{
Watinee Udomkan \\ Department of Science Education, Sakon Nakon Rajabhat University, Thailand \\ Faculty of Education, Khon Kaen University, Thailand \\ Paisan Suwannoi \\ Faculty of Education, Khon Kaen University, Thailand \\ Patcharee Chanpeng \\ Faculty of Education, Khon Kaen University, Thailand \\ Chokchai Yuenyong* \\ Faculty of Education, Khon Kaen University, Thailand \\ *Email: ychok@kku.ac.th
}

Doi:10.5901/mjss.2015.v6n4s3p223

\begin{abstract}
The aim of this study was to investigate Thai pre-service chemistry teachers' performances in their class based on the lens of constructivist learning environment. Methodology regarded interpretive paradigm. Participants included four pre-services chemistry teachers who taught Grade 10,11 and 12 students. Pre-services chemistry teachers' constructivist teaching were observed for one month. After the class, each of them was interviewed to explore their understanding of constructivist view of learning and their approaches to apply constructivist issues in their classes. Their constructivist teaching performance were interpreted based on the framework of the constructivist learning environment survey (CLES) originally developed by Taylor \& Fraser (1991). The CLES provided five dimensions of constructivist learning environment including Personal Relevance (PR), Student Negotiation (SN), Shared Control (SC), Critical Voice (CV), and Uncertainty (UN). The findings indicated that there were rarely appearances of constructivist classroom learning environment in these 4 pre-services chemistry teachers. Mean of rating on CLES for four classrooms revealed that four dimensions of CLES (PR, SN, SC, and UN) were evaluated in level of sometimes. Only critical voice (CV) had mean of rating scale in level of often. The interviewing also suggested that 4 preservice chemistry teachers were not aware of dimensions of constructivist learning environment. It seemed that they could not integrate knowledge of chemistry, pedagogy, and student and school context for their constructivist teaching. This study may have implications for enhancing constructivist teaching for Thai pre-service teacher program.
\end{abstract}

Keywords: Pre-service teachers, classroom learning environment, chemistry

\section{Introduction}

Presently, Thailand required teachers who have ability in teaching science. Education should provide scientific knowledge and skills to people in the changing world. However, school science teaching could not provide classroom learning environment for student centered learning that construct scientific knowledge and skills. The science teaching seems to be passive learning that students listen what teacher talks about and then take note (IPST, 2007). Similarly, the Institute for the Promotion of Teaching Science and Technology; IPST (1995) introduced the concept of science teaching today; science teaching emphasized on the process that the most important thing is student ability to learn by themselves and teachers will only facilitate the event for students to learn on their own rather than tell the students to remember with a regard of maturity and their own experiences and environments before entering the classroom. Thailand Educational Act (1999) rose that teachers had to provide constructivist teaching. The finding of the monitoring and evaluation of education reform in the three-year anniversary of the promulgation of the National Education Act, 1999 found that the instruction that emphasized on the process that the most important thing is students in which the fundamental education was moderately advanced; the operations covered the policy and its implementation but the extension was not applied to all 
schools and assessed in a systematic way. This is due to teachers teaching behavior change with an emphasis on students centered basis requiring time to adjust (Office of the National Education Commission, 2002). It shown that although central policies put efforts to define and promote learning in the classroom as a constructivist as much as possible, but it can still be a problem that most teachers are still accustomed to conduct traditional teaching is that teachers impart knowledge to the students. This problem reflects the determination of policy from the central and the professional development for teachers to complain the policy but not as successful as it could be because there are still a large numbers of teachers felt to comply with the policy.

Constructivism is a theory about "knowing" and "learning" (Bettencourt, 1993; Bodner, 1996; Fosnot, 1996) which asserts that knowledge cannot be directly transmitted but must be actively constructed by learners (Colburn, 2000). Constructivism is viewed as an epistemology or a theory about knowledge and learning (Fosnot, 1996). The basis of constructivism can be described by looking at two approaches to the construction of learning: the cognitive constructivism and social constructivism. Constructivism is an important theory of learning that is used to guide the development of new teaching methods, particularly in science education. However, because it is a theory of learning and not of teaching; constructivism is often either misused or misunderstood. Here we describe the four essential features of constructivism: eliciting prior knowledge, creating cognitive dissonance, application of new knowledge with feedback, and reflection on learning. (Baviskar, Hartle \& Whitney, 2009).

In the past, constructivism is concerned with constructing mental representations of certain structures or features of the world outside that are stored in the human brain. From the personal constructivist perspective, learning is seen as construction of mental models. Knowledge then is something an individual constructs (von Glasserfeld, 1993). However, learning science is seen to involve more than the individual making sense of personal experiences. It is also being initiated into the way of seeing which has been established and found to be fruitful by the scientific community. The social constructivist perspective claims that knowledge can be distributed among the members of a certain community or shared by the community. Knowledge, then, is something that is between the individual and the social (Duit and Treagust, 2003).

The views of both personal and social constructivism should be taken into account for learning science, and both views should be considered in discussion of learning theories (Duit and Treagust, 2003). Social constructivist learning theories suggest that teaching science should be based on students' experience, and relevant their society and culture. This suggests that learning science could be shifted from personal construction by individual learners toward social construction (Hodson and Hodson, 1998) and learning viewed as a process of enculturation in which the aspirant members of a culture learn from their tutors or experts (Osborne, 1996). This argument suggests that learning is a form of cultural apprenticeship and that cognition is situated in specific contexts. This view was expanded from the learning theory of socio-cultural view (Dixon-Kraussm, 1996). With the important socio-cultural view, the researcher needs to consider the influence of different cultural attitudes toward energy learning in Thailand.

There is the long history of a teacher centred approach and a centralised management and monitoring system in Thailand (ONEC, 1999). Therefore, Thai teacher reform aims to change pedagogic philosophy from teacher-centred to student-centred. Teachers need to become truly professional practitioners who have the capacity to identify the most appropriate strategy and design learning experiences for specific learning situations. However, many teachers in Thailand still do not appreciate the need for change. One of the many problems of Thailand educational reform is the problem of having teachers and school administrators as technicians and not professionals. As professionals, they could be expected to understand both the theoretical and the practical nature of theories (ADB, 2002: $10-12$ ). Another problem is the quality of teacher. Sinarat reported (1999),

there was general consensus amongst educators, parents and students about the quality of teacher regressing in recent years. As a solution of these problems, the teacher reforms suggested were (1) to develop new structural and functional requirements for organisation units concerned with improving teacher development; (2) to provide guidelines for new teacher training programs both in-service and pre-service; and (3) to establish quality assurance mechanisms for teachers, including a licensing system for all teachers and teacher education institutions.

The pre-service teacher reform has concentrated on the development of two models. In the first model, a six year program, students will study for a basic degree such as a BSc. and follow that by a two year Graduate Diploma in Education, or MEd. The two years in Faculty of Education is made up of one year of teaching training and a year of professional classroom practice. The second model is a five year BEd. In this model, students have to study teaching training and a major subject area, such as physics, in the first four years. The fifth year is professional classroom practice.

In Thailand, the in-service teacher training has been conducted by the Ministry of Education and the IPST but there were a few training courses offered before emerging educational reform. A consequence of this is that, the majority of Thai teachers lack a clear understanding of the concepts, principles, and processes involved in the new approaches of teaching and learning (ADB, 2002). In the reform, teachers need competencies to implement new approaches of teaching 
and learning. Thai teachers need to have the capacity to provide the range of learning environments to suit the needs of the learners (ONEC, 2000a: 5). For example, teachers could invite local experts into classroom so that children can discuss issues and interact with them and learn from their experience and stories. This enhances to develop learning as grass roots. It is essential that the teachers are given more comprehensive training in theoretical, philosophical and practical aspects of new teaching and learning for appropriate specific learning situations (ADB, 2002: 22).

There is implication of constructivist teaching in Thailand. However, it seemed that there were rarely appearances of constructivist classroom learning environment in Thai context. The investigation of science teaching through the lens of constructivist learning environment may provide us some information of teacher profession development in Thailand. This study adopted the Constructivist Learning Environment Survey (CLES) (Taylor, Fraser, \& Fisher, 1997) to examine the pre-service chemistry teachers' performances regarding constructivist science teaching. The CLES was the instrument that helps teachers and researchers to evaluate the degree of a particular classroom's environment which consists of a constructivist epistemology, and helps teachers reflect their epistemological assumptions and recast their instruction. Recently, the CLES was modified into several versions e.g. Taylor \& Fraser (1991), Taylor, and Fraser \& White (1994), etc.

The theoretical framework of constructivist classroom learning environment regarded Taylor, Fraser, and White (1994)'s constructivist learning environment framework. Taylor et. al. (1994) provided the Constructivist Learning Environment Survey (CLES) based on five dimension of constructivist teaching. These included Personal Relevance (PR), Student Negotiation (SN), Shared Control (SC), Critical Voice (CV), and Uncertainty (UN) (Taylor, Fraser, \& White, 1994;Taylor,1991; Taylor, \& Fisher, 1997).

Personal Relevance (PR) focuses on the connectedness of school science to students' out-of-school experiences, and with making use of students' everyday experiences as a meaningful context for the development of students' scientific and mathematical knowledge.

Uncertainty $(U N)$ refers to the extent to which opportunities are provided for students to experience scientific knowledge as arising from theory-dependent inquiry involving human experience and values, and as evolving, nonfoundational, and culturally and socially determined.

Critical Voice (CV) examines the extent to which a social climate has been established in which students feel that it is legitimate and beneficial to question the teacher's pedagogical plans and methods, and to express concerns about any impediments to their learning.

Shared Control (SC) is concerned with students being invited to share with the teacher control of the learning environment, including the articulation of learning goals, the design and management of learning activities, and the determination and application of assessment criteria.

Student Negotiation (SN) is scale that assesses the extent to which opportunities exist for students to explain and justify to other students their newly developing ideas, to listen attentively and reflect on the viability of other students' ideas and, subsequently, to reflect self-critically on the viability of their own ideas.

This study adopted the Constructivist Learning Environment Survey (CLES) (Taylor, Fraser, \& Fisher, 1997) to examine the pre-service chemistry teachers' performances regarding constructivist science teaching.

Adopting the CLES for monitoring pre-service teachers should enhance them to develop knowledge and skills for constructivist teaching. SNRU produce science teachers. The SNRU science teacher program provide 5 years program. Pre-service teachers have to study in science content in faculty of science and subject about pedagogy in faculty of education during their 4 years. And, then, they have to practice teaching in school for one year (SNRU Ed curriculum, 2008). Examining what pre-service chemistry teachers try to develop their knowledge for chemistry constructivist teaching may provide further information for teacher education in Thailand. This research examined four pre-service chemistry teachers constructing knowledge for constructivist chemistry teaching when they practiced chemistry teaching in school. Therefore, the pre-service teaching experience focus on their successful and barrier of practice constructivist science teaching. The research can clarify how pre-service teacher concern the relationship between chemistry content and pedagogy for science learning. And which level the learning environment in Thais classrooms regarding on constructivist learning environments is at.

The concept of the environment in which students learn science along the constructivist is important to the science learning. The sequence of environment for learning and the constructivist theory of learning can affects student's interaction inside the classroom.

Taking a constructivist perspective on learning, the process of building this professional knowledge base can be understood through the concepts of 'mental structures' i.e., an individual's concepts, schema or mental models and 'conceptual change' (Leach and Scott 2003). In the constructivist view individual learners come to given situations with pre-existing understandings and beliefs and attempt to make sense of experience by making links with their prior 
knowledge. This process may involve little/no change to existing mental structures while in other instances individuals are motivated to change their existing structures and construct different structures to make sense of new information. In other words, they have constructed their own new knowledge. Trainee teachers come to teaching with wide and varied prior experiences and beliefs about the profession and what teaching involves. The in depth professional knowledge and capabilities possessed by an experienced science teacher obviously cannot be built by an individual overnight, and certainly not in a 1-year pre-service training course. Rather, it evolves and accumulates over time and with practice (Nilsson 2008). What then can teacher educators do to help beginner teachers begin to build the foundations they need to start a successful teaching career and equip them with the capabilities and capacity for ongoing professional learning throughout their careers.

Constructivism also can be used for describing the teacher's role in the support and enhancement of student learning. Based on the findings of Learning in Science Project (LISP), Bell (1993) describes one of the teacher's roles as facilitator providing students with activities to shift them from their alternative conceptions to scientific conceptions. The facilitator is seen as involving the teachers in: finding out what the students are thinking; helping students clarify and reflect on their own ideas; challenging students' ideas; helping students change their ideas; helping students find answers for themselves and 'getting them to think'; giving feedback; promoting discussion in the classroom; organising social groupings for learning; creating a supportive, caring atmosphere for learning; motivating and stimulating students to learn; being a co-researcher and learner; providing resources; being a manager and organizer; and planning the curriculum (Bell, 1993). This role of teachers is consistent with the constructivist teachers' role suggested by Bodner (1986) and Osborne (1996). They suggest that a constructivist teacher is a person who can use a variety of techniques to stimulate student alternative conceptions and facilitate student learning. A teacher needs to provide activities through which students can link their own ideas to the new ideas.

Constructivism can be used for the explanation of the nature of scientific knowledge, learning, and teaching. Scientific knowledge is seen as incorporated by the knower. It is viewed not only as a body of knowledge, but also as a student activity. Student activities are embedded in a social context, so the student should be provided with opportunities to represent their own knowledge in a variety of ways and contexts. To provide these opportunities, the teacher does not act as a transmitter of knowledge, but as a scaffolder and facilitator who plays an important role in supporting and enhancing student science learning (Faikhamta, 2007).

Constructivism provides a useful theoretical framework in science teacher education for the understanding and development of the learning of science pre-service teachers. It is regarded as a driving force for science educators to move their attention from teachers' teaching behaviour to teachers' knowledge; how they learn, how they think, and how they construct their knowledge (Bell, 1993; Grossman, 1989; Shulman, 1987).

The implications of a constructivist-based view of learning are that the pre-service teacher must be encouraged to learn and exchange existing knowledge for new knowledge using the various ways suggested for this operation in any other student. They should be provided with the contexts that will help them to make those steps. Within the social context, pre-service teachers construct or reconstruct their own knowledge and beliefs by support and guidance from knowledgeable persons, collaboratively working with other people, and reflecting on their own ideas (Faikhamta, 2007).

The purposes

The main purpose of this study is:

- To examine pre-service chemistry teaching regarding on the constructivist learning environments.

The research questions

Based on the aim of this research, there is a research question:

- Which level the learning environment in Thais classrooms regarding constructivist learning environments is at?

\section{Methodology}

Methodology regarded interpretive paradigm. Four Thai pre-service chemistry teachers' performances were interpreted through the lens of constructivist learning environment.

\subsection{Participants}

Participants included 4 pre-service chemistry teachers (Sai, Woon, Tik, and Chai) who were studying in Sakon Nakon Rajabhat University. They were teaching chemistry in Sakon Nakon and Nakon Phanom provinces, Northeastern of Thailand. These 4 students were included in this study because they were pre-service teachers who held good performance in learning chemistry. They also were advisees of a researcher. 
Sai is pre-service chemistry teacher who hold very good performance in learning chemistry - GPA 3.70. She taught chemistry for Grade 12 students at a middle size secondary school in small town of Sakon Nakon province. There were 37 students in her chemistry class.

Woon is pre-service chemistry teacher who hold good performance in learning chemistry - GPA 3.12. She taught chemistry for Grade 10 students at a small size secondary school in small town of Sakon Nakon province. There were 34 students in her chemistry class.

Tik is pre-service chemistry teacher who hold good performance in learning chemistry - GPA 3.10. She taught chemistry for Grade 11 students at a small size secondary school in a district of Nakon Pranom province. There were 28 students in her chemistry class.

Chai is pre-service chemistry teacher who hold good performance in learning chemistry - GPA 3.00. He taught chemistry for Grade 11 students at a small size secondary school in a small town of Nakon Pranom province. There were 29 students in his chemistry class.

\subsection{Method}

This study had modified the Constructivist Learning Environment Survey (CLES) to observe and interview for investigation of the learning environment in Thai classroom in order to illustrate the pre-service teachers' opinions from the perspective of constructivist. Students who attended their class rated the CLES after each class. Classroom observation and interview were conducted through the lens of CLES. In another word, the five dimensions of CLES were taken into account for classroom observation and interview.

The original CLES was developed by Taylor \& Fraser, 1991 (Taylor and Fraser 1991) with 28 items. We considered that this version is too long to effectively conduct in Thais classrooms, where the spare time is extremely limited. After a review and comparison among variety versions of the CLES (Fraser 1998; Fraser 2007; Johnson and McClure 2004; Nix et al. 2003; Taylor and Fraser 1991; Taylor et al. 1997), this study used the version of CLES with 25 items that was revised by Taylor himself and currently used for collecting the students' reflection through a website (http://surveylearning.moodle.com/), in which they discard the negative meaning questions. Although this version of CLES was not published, it was mentioned in the study of Johnson and McClure (2004). Details of each item and meaning of the scales can be found in this website and in some other papers, for example see Taylor et al. (1991) and Johnson and McClure (2004). Table 1 is a brief summary of the key issues of the CLES, which were taken from Taylor et al. (1997).

All the questionnaires and interview form were carefully translated into Thai by our best knowledge. Therefore, to avoid vague-meaning questions, the Thai CLES questionnaires were checked by two other teachers of the school and 4 pre-service chemistry teachers. The feedbacks were used to revise the questionnaires before implementation. During the interview, more details and explanations were added to help the teachers better understand the questions.

Table 1: Scales, Scale Descriptions and Sample Items of the CLES, taken from Taylor et al. (1997).

\begin{tabular}{|c|c|c|}
\hline Scales & Scale description & Item Sample \\
\hline Personal relevance & Extent to which teachers relate science to students out of school experiences. & $\begin{array}{l}\text { In this class, I learn about the world } \\
\text { outside of school. }\end{array}$ \\
\hline Scientific uncertainty & $\begin{array}{l}\text { Extent to which opportunities are provided for students to experience } \\
\text { scientific knowledge as arising from theory dependent inquiry. }\end{array}$ & $\begin{array}{l}\text { In this class, I learn that science has } \\
\text { changed over time. }\end{array}$ \\
\hline Critical voice & $\begin{array}{l}\text { Extent to which a social climate has been established in which students feel } \\
\text { that it is beneficial to question the teacher's pedagogical plans and methods } \\
\text { to express concerns about any impediments to their learning. }\end{array}$ & $\begin{array}{l}\text { In this class, It's OK for me to ask the } \\
\text { teacher 'Why do I have to learn this?' }\end{array}$ \\
\hline Shared control & $\begin{array}{l}\text { Extent to which students are invited to share with the teacher control of the } \\
\text { learning environment. }\end{array}$ & $\begin{array}{l}\text { In this class, I help the teacher to } \\
\text { plan what I'm going to learn. }\end{array}$ \\
\hline Student negotiation & $\begin{array}{l}\text { Extent to which opportunities exist for students to explain and justify to other } \\
\text { students their newly developing ideas. }\end{array}$ & $\begin{array}{l}\text { In this class, I talk with other students } \\
\text { about how to solve problems. }\end{array}$ \\
\hline
\end{tabular}

\subsection{Data Collection and Analysis}

Pre-service chemistry constructivist teaching was reflected by students. Students rated the CLES after finishing each class. The CLES provided five levels of rating scale (Very Often $=5$, Often $=4$, Some-times $=3$, Seldom $=2$, Never $=1$ ). Mean rating of CLES will be report to reflect the level of constructivist teaching. Four pre-service chemistry classrooms were observed for 4 weeks (two periods a week). One class period in Thai classroom is equal to 50 minutes of teaching. 
The teaching and learning activities relate to five dimensions of CLES were note-taken during the class. Video-tapes were recorded and then were fully fabricated into transcript. The interview was conducted to probe their understanding of constructivist learning and their approaches to apply constructivist issues in their classes. Four pre-service chemistry teachers were asked to reflect their ideas on the mean rating of CLES for their own class. Their ideas about teaching will be categorized regarding to five dimensions of CLES.

\section{Results and Discussion}

Four classroom of pre-service chemistry teaching were interpreted regarding to constructivist learning environment. The results indicated that critical voice is the most focusing scale in these classrooms. Other scales are at the intermediate levels as shown in the Table 2. Mean of rating on CLES for four classrooms revealed that four dimensions of CLES including personal relevance, student negotiation, share control and uncertainty were in level of sometimes. Only critical voice had mean of CLES rating scale in level of often. The classroom observation and interview indicated that 4 preservices teachers emphasized on remembering of chemistry contents rather than constructing of chemistry concepts. If pre-service teachers spent the time too much focusing on remembering of chemistry contents, the classroom learning environment may ....

This may be the case of sometimes appearing on dimension of personal relevance, student negotiation, share control and uncertainty. More importantly, the results from the interview and observation show that the personal relevance and scientific uncertainty sometimes were mixed together in these classes. The paper will clarify how four preservice chemistry teachers could provide their classroom learning environment related to constructivist teaching. Regarding the CLES components, their constructivist learning environment was discussed in following aspects: personal relevance, personal uncertainty, critical voice, share control, and student negotiation.

Table 2: The CLES scale mean rate for chemistry class

\begin{tabular}{|l|c|c|c|c|c|c|c|c|c|c|}
\hline \multirow{2}{*}{ Scale } & \multicolumn{2}{|c|}{ Sai } & \multicolumn{2}{c|}{ Woon } & \multicolumn{2}{c|}{ Tik } & \multicolumn{3}{c|}{ Chai } & \multicolumn{2}{c|}{ All classroom } \\
\cline { 2 - 12 } & Mean rate & Level & Mean rate & Level & Mean rate & Level & Mean rate & Level & Mean rate & Level \\
\hline Personal relevance & 2.79 & ST & 3.07 & ST & 3.17 & ST & 3.40 & ST & 3.35 & ST \\
\hline Scientific uncertainty & 3.35 & ST & 3.15 & ST & 3.21 & ST & 3.46 & ST & 3.35 & ST \\
\hline Critical voice & 3.69 & OT & 3.95 & OT & 3.31 & ST & 3.58 & OT & 3.69 & OT \\
\hline Shared control & 3.02 & ST & 2.95 & ST & 3.15 & ST & 3.65 & OT & 3.02 & ST \\
\hline Student negotiation & 3.15 & ST & 3.56 & OT & 3.30 & ST & 3.40 & ST & 3.15 & ST \\
\hline
\end{tabular}

Note: ST = sometimes, OT = often

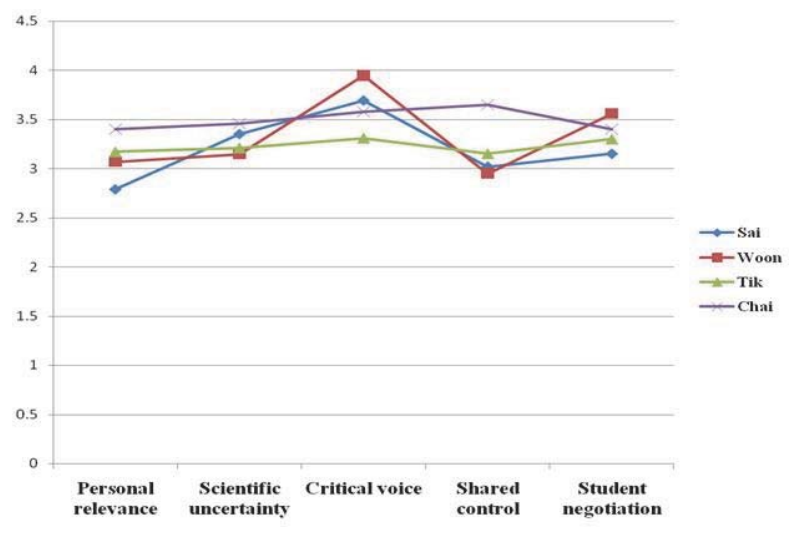

Figure 1: CLES scale mean rate for each chemistry class

The data showed that students perceived pre-service chemistry teachers providing constructivist classroom learning environment in 'sometime' level. Particularly, students preferred the critical voice at the 'often' scale (Fig. 1). It is understandable that pre-service teachers tend to focus on the communication between pre-service teachers and students 
which extent to a social climate established in which students feel that it is beneficial to question the teacher's pedagogical plans and methods to express concerns about any impediments to their learning.

However, the observations seemed that pre-service chemistry teachers' performance of critical voice and personal relevance should be evaluated at 'sometime' level. In addition, scientific uncertainty, student negotiation and shared control seemed to seldom happen in these classrooms not 'sometime' level as mentioned by those students. More importantly, the results from the observation show that the personal relevance and scientific uncertainty were sometimes mixed together in these classes similar to the interviewing. Nevertheless, all pre-service chemistry teachers care about their students' reflections and try to increase more reflections from their students.

\title{
3.1 Personal relevance
}

Personal relevance is an extent to which teachers relate science to students out of school experiences (In this class, I learn about the world outside of school.) (Taylor et al.1997). It showed that students considered that four pre-service chemistry teachers provided constructivist classroom learning environment. Classroom observation could be indicated by pre-service chemistry teachers concerning chemistry learning related to the world outside of school. For example, they assigned students to survey chemical substances in daily life.

According to the interviewing, it seemed that the pre-service teachers follow the textbook; they do not let the student go to the outside. They afraid it may take time for going outside. They were quite worried about the content. This suggests that they were not aware of the constructivist theory for their classroom. The personal relevance is also considered necessary for students. However, sometimes pre-service chemistry teachers let their students go outside of the school. Details of the pre-service teachers' opinion were noted below.

\begin{abstract}
"My subjects are theoretical and statistical such as atomic molecular or stoichiometry. I'm quite worry about the content because the students have to pass their test in the last semester. Therefore I can only introduce the later applications of the subjects to students and cannot relate much the knowledge to the outside of school world ... May be because of the limitation of my knowledge... I still do not understand these subjects very well. I did not have much time to prepare the lesson plan. There is plenty of knowledge which should be taught. Sometimes, I tried to link knowledge to daily life and to students' future career as much as possible." (Sai)
\end{abstract}

\subsection{Scientific uncertainty}

Scientific uncertainty is an extent to which opportunities are provided for students to experience, instance, students learned that atomic models can be changed if we have more evidence. According to the interview, it seems that the preservice only taught in content. They also may misunderstand about constructivist science teaching. They mentioned that students can understand the scientific uncertainty by themselves rather than by teacher challenging for constructing meaning. The details were noted below.

"I taught only the knowledge was confirmed by scientists. It does not depend on another ..."

"I think that students can understand the aspects of 'science has been changing over time' and 'science cannot always provide answer for every problem' during my chemistry teaching without my explicitly talking" (Tik)

\subsection{Critical voice}

Critical voice is an extent to which a social climate has been established in which students feel that it is beneficial to question the teacher's pedagogical plans and methods to express concerns about any impediments to their learning (In this class, It's OK for me to ask the teacher 'Why do I have to learn this?) (Taylor et al., 1997). It seemed students considered that four pre-service chemistry teachers provided constructivist classroom learning environment at 'often' level.

The pre-service teachers considered that the critical voice is necessary for students. The students asked the preservice chemistry teachers very often because they were practicing with teacher internship. There was good relationship between pre-service chemistry teachers and students. The students do not afraid of them. It is a quite strange behavior of students comparing to studying with in-service teachers in that schools. It seemed that the small gap of age between preservice teachers and students allowed students to more participate in the classroom. As pre-service teachers' opinions were noted below. 
"...The students asked me very often. Some students asked me everything that they want to know. Some students do not want to ask. Sometime I have to ask them back "do you know why you must study this content, and by these activities?" "Some students still do not have any feedback but some students do answer my question..And I give more details for them." (Sai)

\subsection{Shared control}

Shared control is an extent to which students are invited to share with the teacher about control of the learning environment (In this class, I help the teacher plan what I'm going to learn.) (Taylor et al.1997). It seemed students considered that four pre-service chemistry teachers provided constructivist classroom learning environment at 'sometime' level.

The pre service chemistry teachers thought that they had reasonable designing classroom activities because they understand well scientific knowledge. So, they preferred to design lesson plan from their understanding scientific knowledge with ignore asking students' sharing ideas. It seemed that they do not aware of the constructivist theory. Details of the pre-service teachers' opinions were noted below.

"... I have a limit of time....I have already prepared my lesson plan for my students....Sometimes I can ask the students to plan some activities together. I asked my students what kinds of activities they like."

"Students do not want to make things more difficult. They prefer to learn and do whatever the teacher assign. They don't want to have more tasks or make things complicated." (Woon)

\subsection{Student negotiation}

Student negotiation is an extent to which opportunities exist for students to explain and justify their newly developing ideas to other students (In this class, I talk with other students about how to solve problems.) (Taylor et al.1997). It seemed students considered that four pre-service chemistry teachers provided constructivist classroom learning environment at 'sometime' level.

Four classroom observation suggested that pre-service teachers try to encourage students to involve in class discussion and give feedback to their friends. Pre-service teachers create chances and foster these activities, many students have feedback to ask some question and to share some ideas. It is quite strange behavior of the students comparing to studying with in-service teachers in that schools. It seemed that the small gap of age between pre-service teachers and students allowed students to more participate in the classroom.

It seemed pre-service teacher considered that student negotiation is necessary for students. They are aware of the constructivist theory. Details of the pre-service teachers' opinions were noted below.

"...if use grade or mark to encourage students, it seems to be not good... I pay a lot of time to student discussion and student activities. " (Sai)

As the results, the pre-service chemistry teachers tried to focus on the constructivist learning environment in sometime level. They always follow the textbook because they think that the students have to take the examination. These classroom seem to only teach the content or subject knowledge rather than construct meaning for scientific concepts, inquiry, and aspects of nature of science. They have their plan already before teaching. Teachers let the student follow with their lesson plan without being aware of the context of the students. They do not want to let the student go to the outside because they think that will spend a lot of time. They let the student know by themselves in personal uncertainty. Wholly, pre-service chemistry teacher require some improvement in their practice in internship to awareness of the constructivist learning environment.

\section{Conclusions}

The constructivist learning environment in these classrooms is at the intermediate level. The highest scale in these classrooms is critical voice. It seemed that the small gap of age between pre-service teachers and students allowed students to more participate in the classroom. Pre-service teachers tend to focus on critical voice, personal relevance, scientific uncertainty, student negotiation and shared control, respectively. Furthermore, the results from the interview show that the personal relevance and scientific uncertainty sometimes were mixed together in these classes. Shared control is also considered necessary but the feedbacks from students are considered low. The shared control issue is the 
one that the pre-service teachers considered very difficult to perform in these context. The findings may suggest some issues of organizing the professional development to enhance Thai teacher provide constructivist learning environment. The study suggested that the CLES items also could be used as monitoring to improve constructivist science teaching.

\section{References}

Aldridge, J.M., Fraser, B.J., Taylor, P.C., and Chen, C.C. 2000. "Constructivist learning environments in a cross-national study in Taiwan and Australia". International Journal of Science Education 22: 37-55.

Asian Development Bank (ADB). 2002. Teacher Development for Quality Learning: The Thailand Education Reform Project, March 2002. Brisbane, Australia: Office of Commercial Services, Queensland University of Technology. Available: http://www.world edreform.com/pub/fulltext4.pdf,

Baviskar, S. N., Hartle R. T. \& Whitney T. 2009. "Essential Criteria to Characterize Constructivist Teaching: Derived from a review of the literature and applied to five constructivist-teaching method articles". International Journal of Science Education 31 (4): 541-550.

Bell, B. 1993. Taking into Account Students' Thinking: A Teacher Development Guide. Hamilton, New Zealand: Centre for Science and Mathematics Education Research, University of Waikato.

Bettencourt, A. 1993. "The construction of knowledge: A radical constructivist view". In K. Tobin. (ed.). The Practice of Constructivism in Science Education. Washington D.C.: AAAS Press.

Bodner, G. M. 1996. "Constructivism: A theory of knowledge". Journal of Chemical Education 63 (10): 873-878.

Chuenmanee C. Chanyoo W. La-the S. Yuenyong C. 2013. "Teacher's Perception about Constructivist Learning". European Journal of Social Sciences 37(1):5-20.

Colburn, A. 2000. "Constructivism: Science education's Grand unifying theory". The Clearing House 74 (1): 9-12.

Dixon-Kraussm, L. 1996. Vygotsky in the Classroom: Mediated Literacy Instruction and Assessment. New York, USA: Longman.

Dorman, J. 2001. "Associations between classroom environment and academic efficacy". Learning Environments Research 4: 243-257.

Duit, R. and Treagust, D.F. 2003. Learning in Science - From Behaviourism Towards Social Constructivism and Beyond, in Fraser, B. J. and Tobin, K.G. (eds.), International Handbook of Science Education: Part one, The Netherlands: Kluwer Academic Publishers, 3 -26 .

Education, SNRU. 2008. Curriculum of Bachelor of Education Program in Curriculum and Instruction (Science Education) http:/lict.edu. snru.ac.th/adviser/course_list.php?course $=208$.

Education, M. O. 2012. Policies of Ministry of Education. Retrieved from http://www.en.moe.go.th/index.php?option=com_content\& view=article\&id=514\&ltemid=120 27 September 2012

Faikhamta, C. Richard K. Coll and Roadrangka V. 2009. "The development of Thai pre-service chemistry teachers' pedagogical content knowledge: From a methods course to field experience". Journal of Science and Mathematics Education in Southeast Asia 32(1), 18-35.

Fosnot, C. 1996. Constructivism: A psychological theory of learning. In C.T. Fosnot. (ed.). Constructivism: Theory, Perpective, and Practice. New York: Teacher College Press, 8-13.

Fraser, B. J. 1998. "Classroom Environment Instruments: Development, Validity And Applications". Learning Environments Research 1: 7-33.

Fraser, B. J. 2007. "Classroom Learning Environments", in S. K. Abell and N. G. Lederman, (eds.), Handbook of Research on Science Education. Mahwah, New Jersey, London: Lawrence Erlbaum Associates, Inc., Publishers.

Gallagher, J. J. 1991. "Uses of Interpretive Research in Science Education". In J. J., Gallagher (Ed.) Interpretive Research in Science Education. Kansas, USA: NARST.

Grossman, P.L. 1989. "A study in contrast: sources of pedagogical content knowledge for secondary English teachers". Journal of Teacher Education 40 (5): 24-31.

Hodson, D. and Hodson, J. 1998. "From constructivism to social constructivism: a Vygotskian perspective on teaching and learning science School". Science Review. 79 (289): $33-41$.

Johnson, B., and McClure, R. 2004. "Validity and Reliability of a Shortened, Revised Version of the Constructivist Learning Environment Survey (CLES)". Learning Environments Research 7: 65-80.

Nilsson, P. 2008. "Teaching for understanding: the complex nature of pedagogical content knowledge in pre-service education". International Journal of Science Education 30 (10): 1281-1299.

Nix, R. K., Fraser, B. J., and Ledbetter, C. E. 2003. Evaluating and Integrated Science Learning Environment (ISLE) - Using a New Form of the Constructivist Learning Environment Survey (CLES). paper presented at the anual meeting of the American Educational Research Association City: Chicago.

Office of the National Education Commission. 1999. The National Education Act of 1999, as amended (no.2) of 2002. Bangkok: Auksornthai. 13-16.

Office of the National Education Commission (ONEC). 1999. Education in Thailand 1999. Bangkok, Thailand: Wattana Panit Printing \& Publishing Company Limited. Available: http://www.onec.go.th/HTML_99/ONEC_PUB/Book/YR42/ed_in_thailand99

Office of the National Education Commission (ONEC). 2000a. Learning Reform: A Learner-Centred Approach. Bangkok, Thailand: Wattana Panit Printing \& Publishing Company Limited.

Osborne, J.F. 1996. Beyond Constructivism. Science Education. 80 (1): 53 - 82.

Özkal, K., Tekkaya, C., and Cakiroğlu, J. 2009. "Investigating 8th Grade Students' Perceptions of Constructivist Science Learning 
Environment". Education and Science 34 (153): 38-46.

Sinlarat, P. 1999. Alternative forms of in-service training in the redevelopment of teachers. Education Management and Financing in Thailand: Review and Recommendations Research Papers, Vol II. Bangkok, Thailand: UNESCO.

Shulman, L. S. 1987. "Knowledge and Teaching: Foundations of the New Reform". Harvard Educational Review 57 (1): 1- 22.

Taylor, P.C., and Fraser, B.J. 1991. CLES: An instrument for assessing constructivist learning environments. Paper presented at the annual meeting of the National Association for Research in Science Teaching, The Abbey, Fontane, Wisconsin.

Taylor, P. C., and Fraser, B. J. 1991. Development of an Instrument for Assessing Constructivist Learning Environments. The annual meeting of the American Educational Research Association. City: New Orleans, LA.

Taylor, P.C., Fraser, B.J, and Fisher, D.L. 1993. Monitoring the development of constructivist learning environments. Paper presented at the annual convention of the National Science Teachers Association, Kansas City, MO.

Taylor, P.C. 1995. Monitoring constructivist classroom learning environments. Paper presented in National Association for Research in Science Teaching (NARST), San Francisco, CA.

Taylor, P. C., Fraser, B. J., and Fisher, D. L. 1997. "Monitoring Constructivist Classroom Learning Environments". International Journal of Educational Research 27 (4): 293-302.

Taylor, P.C., Fraser, B.J. and White, L.R. 1994. A classroom environment questionnaire for science educators interested in the constructivist reform of school science. Paper presented at the annual meeting of the National Association for Research in Science Teaching, Anaheim.

The Institute for the Promotion of Teaching Science and Technology. 1995. Concepts in the Teaching of Science Today. The Vocal Instructors' Workshop Document. Bangkok: IPST.

Von Glaserfeld, E. V. 1993. Questions and answers about radical constructivis. In Tobin, K. (Eds.) The practice of constructivism in science education. Washington, DC: AAAS Press: $23-38$. 